\title{
Groundwater Quality and Arsenic
}

\author{
Anil K Dwivedi* \\ Department of Botany, Deen Dayal Upadhyay Gorakhpur University, Gorakhpur-273009, U.P., India
}

Submission: March 23, 2017; Published: July 11, 2017

*Corresponding author: Anil K Dwivedi, Department of Botany, Deen Dayal Upadhyay Gorakhpur University, Gorakhpur-273009, U.P., India,

Email: anil.k.dwiwedi@gmail.com

Abstract

Arsenic is one of the prominent contaminant, which is degrading the quality of groundwater naturally. In India, arsenic pollution in groundwater is mainly reported from West Bengal. Since its first reported case in early eighties, there are 1312 affected villages, 15 non-municipal and 9 municipalities in 8 districts in the State till date. On an approximation $34000 \mathrm{sq} \mathrm{km}$ area in the State is reported with high concentration of arsenic in drinking water abstracted from tube wells. The pollution is mostly reported from the intermediate water depth of 20-80 meter below ground level.

\section{Introduction}

Water Pollution is an alarm at the global level. The groundwater is continuously decreasing, in anthropogenic pressure as well as naturally. Arsenic is one of the prominent contaminant, which is degrading the quality of groundwater naturally. In India, arsenic pollution in groundwater is mainly reported from West Bengal. Since its first reported case in early eighties, there are 1312 affected villages, 15 non-municipal and 9 municipalities in 8 districts in the State till date. On an approximation $34000 \mathrm{sq} \mathrm{km}$ area in the State is reported with high concentration of arsenic in drinking water abstracted from tube wells. The pollution is mostly reported from the intermediate water depth of 20-80 meter below ground level. The arsenic anomaly in the State is associated with high iron, calcium, magnesium and bicarbonates with low sulphate, fluoride and chloride. The problem of arsenic pollution has been reported to be due to the geological formations of the source material. Occurrence of 'arseno-pyrite' and the change of geochemical environment due to over-exploitation of groundwater or excessive fluctuation of groundwater table.

\section{Reports}

Asadi et al. [1] have studied the assessment and mapping of water pollution of Municipal Corporation of Hyderabad using Remote Sensing and Geographic Information System (RS \&GIS). They observed high concentration of total dissolved solids (TDS), nitrates, fluorides and total hardness in few industrial and densely populated areas indicated deteriorated water quality while the other areas exhibited moderate to good water quality. Bohi et al. [2] Performed physicochemical analysis of bore well drinking water of Nadia territory. They analyzed the water samples during February 2003 to June 2003 in order to assess water quality index (WQI). Joshi et al. [3] evaluated the underground water quality of Vagdodtaluka of Gujarat.

Rajmohan et al. [4] measured the major ion correlation in the groundwater of Kancheepuram region of South India. They analyzed the physicochemical characteristics such as $\mathrm{pH}$, electrical conductivity and total dissolved solids (TDS) and ions like $\mathrm{Ca}^{+2}, \mathrm{Mg}^{+2}, \mathrm{Na}^{+}, \mathrm{K}^{+}, \mathrm{Cl}, \mathrm{HCO}^{3-}, \mathrm{CO}^{-2}, \mathrm{SO}^{-2}, \mathrm{NO}^{3-}$ etc. of the groundwater of bore well and dug wells of the area. The analysis indicated that most of the elements were positively correlated. Dwivedi et al. [5] also reported the crude agricultural practices to be one of the prominent causes of the groundwater pollution in most of the cases, from the rural belt in India.

Rajurkar et al. (2003) have tested the physicochemical and biological parameters of the water of river Umshyrpi at Shillong (Meghalaya). The river is highly polluted by different kinds of wastes viz. domestic wastes, solid wastes and agricultural runoff from the surrounding areas. The results showed that the physicochemical parameters were within the permissible limits, whereas, the biological parameters were exceeding the permissible limits. This indicated the alarm against the potability of the water. Singh and Singh (2003) have surveyed the groundwater markets and equity and reliability to the water access in Western U. P. Bahador et al. [6] have studied the 
seasonal variation of microbial pollution in surface water of Pune city (Maharashtra). They reported that the total viable count in monsoon was more than the summer and the winter seasons. The foecal coliform bacteria were found from all the sites in all the seasons but their number was more in monsoon. They also isolated few pathogenic bacterial species such as Salmonella from three different sites.

Ahmad \& Alam [7] performed physicochemical and toxicological studies of groundwater and industrial effluents in and around Delhi. They determined the chemical contaminants such as mercury, cadmium, chromium, lead, nickel, iron, and zinc in the underground water, drains and Yamuna river. They found that the water quality parameters were very poor, except the samples of upstream.

Garg et al. [8] analyzed the groundwater quality in Western zone of Hissar (Haryana). The results revealed a positive and significant correlation of electrical conductivity with TDS, sodium, calcium, chloride, sulphate and total hardness. They also found that total hardness was positively and significantly correlated with calcium, magnesium, chloride and sulphate, whereas, total alkalinity was positively and significantly correlated with bicarbonate. Anthropecology of the water bodies with respect to development, and politics has been studied in detail and the findings have been elaborated by Dwivedi et al. [9] Tripathi et al. [10]. The flexible policies of the government have also been reported to be also the cause of the flood in India Dwivedi \& Shashi [11]. Singh \& Dwivedi (2011) have discussed the status and statues regarding the ground water.

Lalitha et al. [12] assessed the drinking water quality in selected pilgrim centres near Tiruchirapalli. They analyzed the water samples for various physicochemical and biological parameters and the results were compared with ISI, WHO and USPHS standards. They calculated water quality index (WQI) and suggested suitable treatment methods. Nirmal et al. [13] investigated the physicochemical properties of

groundwater in and around Anand district (Gujarat). They found that there was a wide variation in water quality from sample to sample and the amount of TDS, alkalinity and magnesium hardness was recorded very high in most of the water samples. Singh et al. [14] have analyzed the water quality aspects of some wells, springs and rivers in Udhampur (J \& K). The study showed alkaline nature of groundwater. Calcium and magnesium were the dominating cations and bicarbonate was the major anion in the study area.

Shashi \& Dwivedi [15], Dwivedi \& Prajapati [16] have applied the experimental approach for the study of pollution of the rivers Varuna in Varanasi and river Aami in Gorakhpur, respectively. The same with respect to the groundwater pollution has been elaborated by Shashi \& Dwivedi [17], Dwivedi \& Prajapati [18] tested the groundwater quality status in Amini islands of Lakshadweep. They have reported that the total hardness and salinity were found to be most critical water quality parameter exceeding the permissible limits of drinking water standards. They also observed that the hardness and salinity were comparatively better on the lagoon side as compared to sea side.

Piska et al. [19] studied the heavy metal pollution and its effect on groundwater quality of Jeedimelta industrial area, Hyderabad. They analyzed various heavy metals such as $\mathrm{Cd}, \mathrm{Hg}$, $\mathrm{Pb}, \mathrm{Cr}, \mathrm{Co}, \mathrm{Ba}$ etc. along with $\mathrm{pH}$ and electrical conductivity. The results indicated that all the heavy metals including electrical conductivity values were above the permissible limit of WHO. They found that groundwater was highly polluted and was unfit for domestic, irrigation and for fishery purposes. Jain et al. [20] studied the correlation coefficient of some physicochemical characteristics of groundwater of Jabalpur. They reported that high positive correlation was found between $\mathrm{pH}$ and fluoride, electrical conductivity and $\mathrm{HCO}^{3-}, \mathrm{SO}_{4}^{-2}$ and $\mathrm{Na}^{+}, \mathrm{Ca}^{+2}$ and $\mathrm{NO}^{3-}$, $\mathrm{Na}^{+}$and $\mathrm{Cl}^{-}, \mathrm{K}^{+}$and $\mathrm{C}^{-}$and high negative correlation was obtained between $\mathrm{Cl}$ - and $\mathrm{PO} 4-3$ and $\mathrm{pH}$ and $\mathrm{PO}^{-3}$.

Azmi \& Banerjee [21] performed biological stabilization of textile waste and dye stuff industrial waste. They have suggested that the effluents from textile and dyeing industries polluted the groundwater of the adjoining area. Suriyanarayanan et al. [22] evaluated the groundwater of Kanchipuram and observed that the groundwater was polluted by a waste paper based paper mill effluent. Wagh \& Shrivastava [23] evaluated the impact of heavy metals on soil and groundwater. Tandel \& Oza [24] have implied "Powdered Activated" and "Powdered Commercial Charcoal" as adsorbents for removal of copper and nickel from waste water of electroplating industry. They found that higher efficiency value of adsorption was obtained at lower dose of powdered activated charcoal which removed $61.28 \%$ copper and $50.35 \%$ nickel at a maximum dose of $25 \mathrm{~g} / \mathrm{L}$, whereas similar dose of powdered commercial charcoal removed $28.74 \%$ copper and $24.80 \%$ nickel respectively. Jogi \& Ilyas [25] used "Maize Husk" for the removal of iron from industrial waste water. They observed that iron was heavily adsorbed on the maize husk and it was found to be very effective for removal of iron [26-28].

\section{Conclusion}

These selected studies indicate towards the importance of the groundwater and its need for the future. It is also indicated that sustainable development should be preferred over the simple development. Arsenic, though it is contaminating the groundwater naturally, but the human interference in this phenomenon, directly or indirectly cannot be over-ruled.

\section{References}

1. Asadi SS, Vuppala P, Reddy MA (2005) Assessment and mapping of water pollution indices in zone-III of Municipal Corporation of Hyderabad using Remote Sensing Geographic Information System. J Environ Sci Eng 47(1): 13-20.

2. Bohi DK, Raj DS, Mehta YM, Chauhan MB, Machhar MT (2005) Physicochemical analysis of bore well drinking water of Nadia territory. Asian J Chem 17(1): 404-408. 
3. Joshi JD, Vora JJ, Sharma S, Patel NK, Kothari OK, et al. (2005) Underground water quality of Vagdodtaluka (Gujarat). Asian J Chem 17(1): 634-636

4. Rajmohan N, Elango L, Ramachandran S, Natarajan M (2003) Major ion correlation in groundwater of Kancheepuram region, South India. Indian J Environ Health 45(1): 5-10.

5. Dwivedi AK, Singh G, Shashi (2010) Crude Agricultural Practices and Water Pollution. Indian Science Cruiser 24(5): 21-25.

6. Bahador N, Baseri SM, Patil DN, Kapadnis BP (2005) Seasonal variation of microbial pollution in surface water of Pune city (Maharashtra). Nat Envir Pollut Technol 4(1): 53-56.

7. Ahmad A, Alam M (2003) Physicochemical and toxicological studies of industrial effluents in and around Delhi and groundwater quality of some areas in Delhi city. Chem Envir Res 12(1-2): 5-13.

8. Garg VK, Gupta R, Khurana B (2001) Groundwater quality in western zone of Hissar city (Haryana). Indian J Envir Toxicol 11(2): 58-61.

9. Dwivedi AK, Hasan H, Shashi (2009) Anthropecology of Water Bodies. In: Trivedi PC (Eds.), Plant Physiology in Agriculture and Forestry. Aavishkar Publishers and Distributors, Jaipur, India, pp. 248-254.

10. Tripathi P, Shashi, Dwivedi AK (2010) Development, Environment and Politics. In: Dwivedi AK, Tripathi SC (Eds.), Environment and Biodiversity. Lambert Academic Publisher (LAP), Germany, pp. 183-189.

11. Dwivedi AK, Shashi (2010) Development Policies and Flood in India Journal of Flood Engineering 1(1): 89-92.

12. Lalitha S, Kasthuri R, Banumathi K, Swapna S (2004) Assay of drinking water quality in selected pilgrim centres near Tiruchirapalli (Tamilnadu). Indian Journal Of Environmental Protection 24(1): 3340 .

13. Nirmal KJI, Bhatt T, Kumar RN, Patel M (2003) Physicochemical properties of ground waters in and around anand district (Gujarat). Indian J Envir Prot 23(11): 1248-1253.

14. Singh O, Kumar V, Rai SP (2005) Water quality aspects of some wells, springs and rivers in parts of the Udhampur district (J \& K). J Environ Sci Eng 47(1): 25-32.

15. Shashi, Dwivedi AK (2010) River Pollution and Solution. Publisher: New Central Book Agency (P) Ltd., Calcutta, ISBN: 978-81-7381-622-2.

This work is licensed under Creative

Commons Attribution 4.0 Licens

DOI: 10.19080/JOJCS.2017.03.555617
16. Dwivedi AK, Prajapati UB (2011) Pollution in Tropical River Ami- An Experimental Approach. Publisher: Lambert Academic Publisher (LAP), Germany, ISBN: 978-3-8433-7712-6.

17. Dwivedi AK, Singh R, Shashi (2008) Groundwater Pollution: Causes and Impact. Indian Science Cruiser 22(4): 29-33.

18. Prasad NB, Mansoor OA (2005) Assessment of groundwater quality status in Amini island of Lakshadweep. J Environ Sci Eng 47(1): 69-74.

19. Piska RS, Swamy PY, Parvathi R (2004) Heavy metal pollution and its effect on groundwater quality of Jeedimelta industrial area, Hyderabad (Andhra Pradesh). J Nat Conserv 16(2): 361-367.

20.Jain CK (2004) Groundwater quality of district Dehradun (Uttarakhand). Indian J Envir Ecoplan 8(2): 475-484.

21.Azmi W, Banerjee UC (2002) Biological stabilization of textile waste and dye stuff industrial waste. Indian Chemical Engineer 44(4): 230234 .

22.Suriyanarayanan S, Jayakumar D, Devi MP, Balsubramanian S (2003) Monitoring of groundwater in and around waste paper based mill in Kanchipuram. Indian Journal of Environmental Protection 23(9): 1033-1037.

23. Wagh SP, Shrivastva VS (2005) Impact of heavy metals on soils and groundwater. Nat Envir Pollut Technol 4(1): 93-96.

24. Tandel MA, Oza BN (2005) Effect of powdered commercial and activated charcoal on removal of copper and nickel from waste water of electroplating industry. Asian J Chem 17(1): 415-422.

25. Jogi MM, Ilyas AA (2003) Non conventional utilization of maize husk for the removal of iron from industrial waste water. Biosciences, Biotechnology Research Asia 1(1): 63-66.

26. De AK (2003) Removal of lead and cadmium from water by adsorption on coal fly ash. Chem Envir Res 12(1-2): 31-36.

27. Dhaka University Hospital (2003) Arsenik: King of poison. Bangladesh.

28. Singh DR, Singh RP (2003) Groundwater markets and the issues of equity and reliability to water access: A case of Western U. P. Indian J Agric Econ 58(1): 115-127.

\section{Your next submission with Juniper Publishers will reach you the below assets}

- Quality Editorial service

- Swift Peer Review

- Reprints availability

- E-prints Service

- Manuscript Podcast for convenient understanding

- Global attainment for your research

- Manuscript accessibility in different formats

( Pdf, E-pub, Full Text, Audio)

- Unceasing customer service

Track the below URL for one-step submission

https://juniperpublishers.com/online-submission.php 